\title{
Poszukiwanie koncepcji kształcenia kadr dla administracji publicznej w Polsce
}

\section{Streszczenie}

Badania prowadzone nad funkcjonowaniem administracji publicznej mają charakter interdyscyplinarny. Analizowanie kwestii funkcjonowania administracji publicznej wymaga systemowego spojrzenia, w którym istotnym elementem jest układ stosunków pomiędzy całym systemem i poszczególnymi podsystemami administracji publicznej a jej otoczeniem zewnętrznym. To ujęcie wywodzi się z nauk o zarządzaniu. Znajduje ono swoje odzwierciedlenie w nauce administracji. Szczególnym podsystemem administracji publicznej wymagającym ujęcia interdyscyplinarnego jest podsystem społeczny. W polskim systemie administracji publicznej podsystem społeczny stanowią pracownicy tworzący korpus służby cywilnej oraz inni pracownicy zatrudnieni w urzędach i pozostałych strukturach administracji publicznej. Kształtowanie kadry administracji wiąże się nie tylko z samym naborem odpowiednio wykształconych kandydatów do pracy w urzędach organów administracji publicznej. Bardzo ważne jest kształtowanie odpowiednich postaw etycznych urzędników zarówno administracji rządowej, jak i samorządowej. Powinni oni znać zasady etyki urzędniczej. Nie jest jednak możliwe skodyfikowanie wszystkich norm etycznych pracownika administracji publicznej, a więc należy w tym zakresie stosować ogólne normy prawa moralnego. Obecnie absolwenci kierunków studiów wyższych przygotowujących do pracy w administracji są wprawdzie na ogól odpowiednio przygotowani do analizowania aktów normatywnych, wydawania decyzji administracyjnych czy w ogóle rozumienia zasad systemu prawnego, ale brak im podstaw do uwzględniania w odpowiednim stopniu kwestii związanych z etyką działania i poszanowaniem przyjętych w społeczeństwie wartości.

Słowa kluczowe: korpus służby urzędniczej, etyka urzędnicza, normy moralne, program studiów

1 Prof. dr hab. Stanisław Wrzosek - Wydział Prawa, Prawa Kanonicznego i Administracji Katolickiego Uniwersytetu Lubelskiego Jana Pawła II; e-mail: wrzosek@kul.pl; ORCID: 0000-0001-5557-5758. 


\title{
Searching for the concept of staff training for public administration in Poland
}

\begin{abstract}
Research on the functioning of public administration is interdisciplinary. The analysis of the functioning of public administration requires a systemic view in which the system of relations between the entire system and individual subsystems of public administration on the one hand and its external environment on the other is an important element. This approach comes from the management sciences. It is reflected in the science of administration. The social subsystem is a particular subsystem of public administration requiring an interdisciplinary approach. In the Polish system of public administration, the social subsystem consists of employees forming the civil service corps and other staff employed in offices and other public administration structures. Formation of the administration staff is associated not only with the recruitment of properly educated candidates for work in the offices of public administration bodies. It is very important to shape appropriate ethical attitudes of officials of both government and local government administration. They should know the rules of official ethics. However, it is not possible to codify all the ethical standards of a public administration employee, so the general standards of the moral law should be applied in this respect. Currently, graduates of higher education studies preparing for work in administration are generally adequately prepared for analysing normative acts, issuing administrative decisions or understanding the rules of the legal system in general, but they lack the basis for addressing to a sufficient extent the issues related to ethics of acting and respecting the values adopted in the society.
\end{abstract}

Keywords: official service corps, official ethics, moral standards, studies' curriculum 


\section{Administracja publiczna jako interdyscyplinarny obiekt zainteresowania}

Badania prowadzone nad funkcjonowaniem administracji publicznej mają w coraz szerszym zakresie charakter interdyscyplinarny. Wymagają one systemowego ujęcia, w którym istotnym elementem jest podsystem celów i wartości organizacji. Ujęcie administracji publicznej jako organizacji wymaga spojrzenia na nią nie tylko z punktu widzenia nauki prawa administracyjnego, ale i wykorzystania także pozostałych dyscyplin związanych z klasyczną triadą nauk administracyjnych, a mianowicie nauki administracji oraz nauki polityki administracyjnej. Ujęcie dyscyplinarne wymaga nawet wyjścia poza dziedzinę nauk prawnych i oparcia się na rozważaniach związanych z dziedziną nauk społecznych i dziedziną nauk ekonomicznych, a w szczególności nauk o zarządzaniu. Na szczególną uwagę zasługuje w tym zakresie cel (a właściwie cele) działania administracji publicznej wiążący się bezpośrednio z jej misją. Jest to bardzo dobry przykład podsystemu administracji publicznej, który można analizować z punktu widzenia różnorodnych dyscyplin naukowych. Wynika to z faktu, że jest on określany za pomocą aktów normatywnych, które znajdują się w polu zainteresowania nauki prawa administracyjnego (jako jego źródła). Kwestia ta również może być - a raczej powinna być - analizowana z punktu widzenia nauki polityki administracyjnej, i to zarówno polityki administracyjnej określającej rolę administracji w strukturze państwa, jak i polityki administracyjnej określającej, w jaki sposób administracja ma realizować powierzoną jej rolę w państwie. Następnie pojawia się kwestia skuteczności realizacji postawionego przed administracją celu, a to zagadnienie wymaga spojrzenia z punktu widzenia nauki administracji, która wykorzystuje w coraz szerszym zakresie osiągnięcia nauk o zarządzaniu.

Analizowanie kwestii funkcjonowania administracji publicznej wymaga systemowego spojrzenia, w którym istotnym elementem jest układ stosunków pomiędzy całym systemem i poszczególnymi podsystemami administracji publicznej a jej otoczeniem zewnętrznym. Otoczenie to stanowią zarówno całe społeczności, jak i poszczególni obywatele czy ich grupy oraz wszelkie inne podmioty będące stronami w postępowaniu administracyjnym albo w jakikolwiek inny sposób wpływające na administrację lub których sytuację administracja kształtuje. Zwrócenie uwagi na odbiór działań administracji poprzez jej otoczenie społeczne stanowi ważny element badań związanych z poszukiwaniem optymalnych rozwiązań 
w zakresie realizacji misji, którą ona realizuje. Potrzebne jest $\mathrm{w}$ tym zakresie przede wszystkim spojrzenie uwzględniające analizowanie stosowania przez administrację prawnych form działania. Jednak to nie wystarcza i należy uwzględnić także przepisy materialnego prawa administracyjnego. Przepisy proceduralne są bowiem następstwem uregulowań zawartych w prawie materialnym.

Szczególnym podsystemem administracji publicznej wymagającym ujęcia interdyscyplinarnego jest podsystem społeczny. Wprawdzie kompetencje w rozumieniu prawnym są przypisane organom administracji publicznej, ale każde rozstrzygnięcie związane $\mathrm{z}$ realizacją tych kompetencji wymaga jego przygotowania, a to należy do sfery zadań urzędu będącego aparatem pomocniczym organu. W tym zakresie w nauce administracji rozróżnia się decydenta formalnego, do którego należy podjęcie rozstrzygnięcia mającego postać prawnej formy działania administracji, i decydenta materialnego, do którego należy przygotowanie wskazanego rozstrzygnięcia.

\section{Kadry administracji publicznej jako jej podsystem społeczny}

W literaturze z zakresu teorii organizacji i zarządzania podnosi się, iż podsystem społeczny organizacji, czyli ludzie, są najważniejszym i odróżniającym się od innych podsystemów składnikiem organizacji. Inne podsystemy, na przykład podsystemy celów, struktury czy techniki są tylko podsystemami sztucznymi. Są one określane i tworzone przez podsystem społeczny i uważane są za instrumenty działania podsystemu społecznego ${ }^{2}$. Powoduje to, że w naukach o zarządzaniu, a także w związanej z nimi nauce administracji, duży nacisk kładzie się na kwestie społeczne, zarówno w układzie wertykalnym, czyli pracownik (urzędnik) i jego przełożony (np. organ administracji będący jednocześnie kierownikiem urzędu), jak i w układzie horyzontalnym, czyli pracownik i pozostałe osoby zatrudnione na tym, co on poziomie $\mathrm{w}$ organizacji (urzędzie). W naukach o zarządzaniu zagadnienia związane ze sprawami o charakterze społecznym w organizacji określa się jako "gospodarowanie zasobami ludzkimi". Gospodarowanie zasobami ludzkimi rozumiane jest w tych naukach jako „działania organizacji nastawione na przyciąganie, rozwój i utrzymywanie efektywnie działającej siły roboczej”"3. W odniesieniu do administracji określenie „siła robocza” nie jest być może odpowiednie, ale sens przytoczonego określenia oddaje charakter podsystemu społecznego.

\footnotetext{
2 A.K. Koźmiński, W. Piotrowski (red.), Zarządzanie. Teoria i praktyka, Warszawa 1998, s. 56.

3 R.W. Griffin, Podstawy zarzadzania organizacjami, Warszawa 1996, s. 419.
} 
Kierowanie podzespołem społecznym, określane również jako zarządzanie zasobami ludzkimi, dotyczy następujących kwestii:

skutki zmiany zarządzania mającej na celu wsparcie elastycznego podejścia do akceptacji nowych praktyk w miejscu pracy,

- generowanie dużego wkładu do rozwoju organizacyjnego,

$\square$ bycie normatywnym (nakazowym) i podejmującym nowe działania w przeciwieństwie do bycia pełnym respektu dla prawa pracy, które to podejście jest typowe dla zarządzania personelem,

$\square$ zdefiniowanie relacji pracowniczych przez powstanie kultury organizacyjnej sprzyjającej współpracy i zaangażowaniu,

$\square$ przyjęcie długoterminowego punktu widzenia w celu integracji zasobów ludzkich w koherentną całość,

$\square$ podkreślanie potrzeby bezpośredniej komunikacji,

$\checkmark$ rozwój kultury organizacyjnej,

zachęcanie pracowników do brania udziału w grupach roboczych,

rozwijanie umiejętności pracowników w dłuższej perspektywie czasowej, nieskupiające się wyłącznie na ich bieżących obowiązkach i zakresie odpowiedzialności ${ }^{4}$.

Większość wymienionych kwestii można z całą pewnością odnieść do kierowania podsystemem społecznym w administracji publicznej, a w szczególności zagadnienia elastycznego podejścia do nowych praktyk w miejscu pracy, przyjęcia długoterminowego punktu widzenia w celu integracji zasobów ludzkich w koherentną całość czy rozwijanie umiejętności pracowników w dłuższej perspektywie czasowej ${ }^{5}$. Przy rozważaniu aspektu społecznego w administracji publicznej należy wprawdzie zasygnalizować kwestię podziału struktur w organizacjach na formalne, nieformalne i pozaformalne, ale faktyczne znaczenie w realizacji misji we współczesnej administracji mają tylko struktury formalne. W przypadku administracji istnienie struktur nieformalnych i pozaformalnych nie sprzyja powodzeniu całości, jaką jest system administracji publicznej. W przypadku bowiem tego systemu wymagane jest funkcjonowanie układów formalnych, o czym jako jeden z pierwszych przekonywał Max Weber w swojej koncepcji biurokratycznego modelu administracji.

4 J. Sutherland, D. Canwell, Klucz do zarzadzania zasobami ludzkimi. Najważniejsze teorie, pojęcia, postaci, Warszawa 2007, s. 296 i n.

5 S. Wrzosek, System administracji publicznej. Systemowe determinanty nauki administracji, Lublin 2008, s. 52 . 
W polskim systemie administracji publicznej podsystem społeczny stanowią pracownicy tworzący korpus służby cywilnej oraz inni pracownicy zatrudnieni w urzędach i pozostałych strukturach administracji publicznej. W literaturze przez pojęcie pracowników administracji rozumie się „osoby wykonujące czynności związane z funkcjonowaniem administracji publicznej oraz czynności administracyjne w innych niż jednostki administracji urzędach państwa, bez względu na sposób nawiązania z nimi stosunku pracy"6.

Od tego, jak zostanie ukształtowany „system złożony z ludzi organizowanych w celu stałej, systematycznej, skierowanej ku przyszłości, realizacji dobra wspólnego jako misji publicznej, polegającej głównie (choć nie wyłącznie) na bieżącym wykonywaniu ustaw, wyposażonych w tym celu we władztwo państwowe oraz środki materialno-techniczne" ${ }^{\prime 7}$ zależy powodzenie realizacji zadań państwa określanych jako administracja. Wspomniane ukształtowanie kadry administracji wiąże się nie tylko z samym naborem odpowiednio wykształconych kandydatów do pracy w urzędach rozumianych jako aparat pomocniczy organów administracji publicznej. Bardzo ważne jest kształtowanie odpowiednich postaw etycznych urzędników zarówno administracji rządowej, jak i samorządowej.

\section{Wpływ otoczenia wewnętrznego administracji na realizację jej misji}

Kwestię etyki urzędników z punktu widzenia nauki administracji należy określić jako zdecydowanie najważniejszy element otoczenia wewnętrznego administracji. Zainteresowanie tym zagadnieniem znajduje swoje odzwierciedlenie nie tylko w nauce administracji, ale $i$ w innych dziedzinach wiedzy, a przede wszystkim $w$ dziedzinie nauk filozoficznych. W ramach tych nauk etyka jako dyscyplina naukowa jest zaliczana do dziedziny filozoficznych nauk praktycznych. W ramach etyki wyróżnia się etykę normatywną i etykę opisową ${ }^{8}$. Z punktu widzenia kształtowania

6 E. Ura, E. Ura, Prawo administracyjne, Warszawa 2006, s. 257.

7 Określenie administracji autorstwa I. Lipowicz (Z. Cieślak, I. Lipowicz, Z. Niewiadomski, Prawo administracyjne. Część ogólna, Warszawa 2002, s. 27 i n.).

8 „Etyka normatywna zajmuje się ustalaniem tego, co jest moralnie dobre, a co złe, co jest obowiązujące, a co wzbronione, oraz - na podstawie przyjętych ocen związanych z nimi powinności - wytyczaniem szczegółowych dyrektyw, tj. norm moralnie pozytywnego postępowania, i wskazywaniem sposobów takiego przekształcania obiegowej moralności, by dostosować ją do przyjętego ideału moralnego; jest formułowana w różnych strukturach językowych oraz w różnych kontekstach światopoglądowych i filozoficznych, kierowana do różnych adresatów, formułowana w kwestiach ogólnych i szczegółowych (...). Etyka opisowa (deskryptywna) zajmuje się opisem i wyjaśnianiem moralności rzeczy wiście przyjmowanej (obiegowej) w różnych epokach i środo- 
współczesnej administracji publicznej większe znaczenie ma raczej etyka normatywna, chociaż z punktu widzenia wykrywania prawidłowości rozwoju etyki urzędniczej ważne są również analizy prowadzone w ramach etyki opisowej. „Etyka urzędnicza jako wyodrębniona dyscyplina naukowa ma charakter normatywny. Może być uprawiana przynajmniej w trzech ujęciach: proceduralnym, arteologicznym i integralnym ${ }^{\prime \prime}$. Wyróżnione zostały trzy rodzaje źródeł etyki urzędniczej, a mianowicie: 1) normy inkorporowane do systemu prawa; 2) normy nieinkorporowane do systemu prawa (deklaracje, uchwały); 3) normy pozakodeksowe (moralność społeczna) $)^{10}$.

W literaturze podaje się, że do „najbardziej znanych kodeksów etycznych służby publicznej, zawierających katalog podstawowych wartości, jakich powinni przestrzegać funkcjonariusze publiczni, należą tzw. Zasady Nolana opracowane w Wielkiej Brytanii"11.

Zasady te, określane jako "Siedem zasad życia publicznego", sformułowane zostały w tzw. Raporcie Nolana ${ }^{12}$. Koncepcja etyki życia publicznego zaproponowana przez Komitet Nolana składa się z następujących siedmiu zasad:

1) bezinteresowność - nakaz kierowania się wyłącznie interesem publicznym;

2) rzetelność - osoba sprawująca urząd publiczny nie może działać w celu uzyskania osobistych korzyści finansowych lub materialnych oraz korzyści swojej, rodziny lub przyjació1;

3) obiektywizm - osoba sprawująca urząd publiczny musi działaći podejmować decyzje bezstronnie, uczciwie oraz merytorycznie, posługując się najlepszymi dowodami oraz bez dyskryminacji lub uprzedzeń;

wiskach społecznych, wskazywaniem źródeł, struktury, funkcji moralności jako formy świadomości społecznej i wykrywaniem prawidłowości rozwoju", R. Wiśniewski, Etyka, [w:] Wielka Encyklopedia PWN, t. 8, Warszawa 2002, s. 393.

9 T. Barankiewicz, Etyka urzędnicza - pojęcie, [w:] M. Domagała, A. Haładyj, S. Wrzosek (red.), Encyklopedia prawa administracyjnego, Warszawa 2010, s. 284. Wg tego autora etyka w ujęciu proceduralnym wiąże się z określaniem podstawowych zasad i wartości kształtujących wysoką jakość działań administracji publicznej; etyka w ujęciu arteologicznym wiąże się z poszukiwaniem osobowego wzorca urzędnika, który jest pożądany z punktu widzenia funkcjonowania administracji publicznej; ujęcie integralne łączy natomiast w sobie ujęcia proceduralne i arteologiczne (ibidem, s. 284).

10 Ibidem.

11 D. Sześciło, A. Mednis, M. Niziołek, J. Jakubek-Lalik, Administracja i zarządzanie publiczne. Nauka o wspótczesnej administracji, Warszawa 2014, s. 215.

12 Raport Nolana został opracowany przez powołany w 1994 r. przez premiera Wlk. Brytanii J. Majora Komitet Standardów Życia Publicznego (popularnie określany jako Komitet Lorda Nolana). Szeroko na ten temat patrz: P. Skuczyński, Infrastruktura etyczna administracji publicznej, [w:] System prawa administracyjnego, t. 13: R. Hauser, Z. Niewiadomski, A. Wróbel (red.), Etyka urzędnicza i etyka stużby publicznej, Warszawa 2016, s. 119 i n. 
4) odpowiedzialność lub rozliczalność - osoba sprawująca urząd publiczny ponosi odpowiedzialność wobec społeczeństwa za swoje decyzje i działania oraz musi poddać się wszelkiej kontroli właściwej dla sprawowanego przez nią urzędu;

5) otwartość (jawność) - osoba sprawująca urząd publiczny powinna działać oraz podejmować decyzje w sposób otwarty i transparentny;

6) uczciwość (obecnie: nakaz prawdomówności) - osoba sprawująca urząd publiczny jest obowiązana do zgłoszenia wszelkich prywatnych interesów mających związek z pełnionymi obowiązkami oraz do podejmowania działań w celu rozwiązywania wszelkich pojawiających się sprzeczności w sposób zapewniający ochronę interesu publicznego;

7) przywództwo - osoba sprawująca urząd publiczny powinna manifestować wskazane wyżej zasady własnym zachowaniem ${ }^{13}$.

Wskazane zasady należy rozpatrywać nie tylko z punktu widzenia moralności czy wrażliwości sumień pracowników administracji publicznej. Należy je także uwzględniać przy rozpatrywaniu skuteczności funkcjonowania administracji, a więc z punktu widzenia mającej swe korzenie w teorii organizacji i zarządzania nauce administracji. Podstawą zaprezentowanego wyżej stwierdzenia, że zasady etyczne powinny być rozważane także z punktu widzenia osiągnięcia powodzenia misji administracji publicznej, jest przekonanie o nierozerwalności analizy zachowań i systemów wartości uczestników organizacji z analizą innych czynników o charakterze organizacyjnym, ekonomicznym czy prawnym.

Z czynnikami o charakterze prawnym wiąże się przede wszystkim zagadnienie sposobów wzmacniania i utrwalania zachowań pracownika administracji. Wskazuje się w tym zakresie - oprócz uwrażliwienia sumień pracowników - na dwa najczęściej spotykane sposoby: a) rozbudowywanie i popularyzacja tak zwanych kodeksów etycznych pracownika administracji publicznej, b) ujmowanie norm etyki pracownika administracji publicznej w normy prawa stanowionego ${ }^{14}$. Nie można więc oddzielić kwestii związanych z etyką urzędniczą od zagadnień realizacji misji administracji publicznej. Realizacja tej misji zależy bowiem od sposobu postępowania pracownika administracji, a w szczególności od sposobu rozumienia przez niego sposobów osiągania zamierzonego celu. Tak więc zagadnienia o charakterze etycznym jako element otoczenia wewnętrznego powinny być z całą pewnością brane pod uwagę przy rozpatrywaniu kwestii związanych ze skutecznością osią-

\footnotetext{
13 Ibidem, s. 121-122.

14 A. Błaś, J. Boć, J. Jeżewski, Administracja publiczna, Wrocław 2003, s. 277.
} 
gania celów społecznych przez organizację (czyli system), jaką jest administracja publiczna.

Wskazane kwestie etyczne w działalności administracji publicznej związane są z „prawem do dobrej administracji”. Prawo do dobrej administracji, mające swe źródło w Karcie Praw Podstawowych Unii Europejskiej, a w szczególności jej art. 41 ust. 1, który brzmi „Każdy ma prawo do bezstronnego i rzetelnego załatwienia jego sprawy w rozsądnym terminie przez instytucje, organy i agencje Unii"15, jest istotną wskazówką dotyczącą kształtowania postaw pracowników administracji publicznej. Nie oznacza ono we współczesnym rozumieniu tylko zespołu uprawnień rodzących obowiązek działania organów zgodnie z prawem $^{16}$. Z całą pewnością działanie ludzi zatrudnionych w administracji, niezależnie czy piastują funkcje organów czy są szeregowymi pracownikami urzędów, musi być zachowaniem określanym jako etyczne, a więc być uczciwe, rzetelne i odpowiedzialne.

W literaturze z zakresu nauki prawa administracyjnego wskazuje się na nierozerwalny związek pomiędzy etyką urzędniczą a konstytucyjną zasadą rzetelności i sprawności działania instytucji publicznych. Związek ten jest praktycznym, choć również normatywnym, dowodem doniosłości refleksji etycznej i stosowania jej efektów we współczesnej administracji publicznej ${ }^{17}$.

Pojęcie etyki urzędniczej wiąże się z zagadnieniem podmiotu moralnego służby urzędniczej. Działania administracji nie opierają się bowiem na anonimowych i abstrakcyjnych organach czy innych instytucjach. Podmiotem działań podejmowanych w ramach administracji jest osoba ludzka, charakteryzująca się określonymi kwalifikacjami, doświadczeniem życiowym, przekonaniami, dojrzałością, cechami charakteru oraz zaletami moralnymi ${ }^{18}$. Każdy pracownik, wchodząc do administracji rozumianej jako organizacja, wnosi ze sobą system wartości wiążący się z jego rozumieniem interesu publicznego. Ten system wartości może być kształtowany nie tylko poprzez normy wynikające z systemu prawa, ale także przez czynniki pozaprawne, takie jak wpływ bezpośredniego otoczenia wewnętrznego, nabywane doświadczenie czy sposób zorganizowania pracy, w tym przebieg procesu decyzyjnego. Kluczowy w tym zakresie jest jednak proces kształcenia związany z podnoszeniem kwalifikacji.

15 Dz. Urz. UE C 83/389, 30.3.2010, https://bip.ms.gov.pl/Data/Files/_public/bip/prawa_czlowieka/ onz/karta.pdf (dostęp: 6.07.2018).

16 T. Barankiewicz, Etyczne treści prawa do dobrej administracji, [w:] System prawa administracyjnego..., t. 13, s. 43.

17 H. Izdebski, Etyka urzędnicza a zasada rzetelności i sprawności działania instytucji publicznych w demokratycznym państwie prawnym, [w:] System prawa administracyjnego..., t. 13, s. 61.

18 T. Barankiewicz, Urzędnika etyczne predyspozycje (cnoty), [w:] M. Domagała, A. Haładyj, S. Wrzosek (red.), op. cit., s. 287 i n. 
W literaturze podkreśla się, że nie jest możliwe skodyfikowanie wszystkich norm etycznych pracownika administracji publicznej. Należy w tym zakresie stosować ogólne normy prawa moralnego, przede wszystkim takie, jak: czyń dobro, unikaj czynienia zła, bądź prawdomówny, okaż należytą ofiarność, bądź cierpliwy, bądź szlachetny, udzielaj pomocy drugiemu człowiekowi, służ radą, chroń swą godność, nie naruszaj godności drugiego człowieka, kieruj się zaufaniem do drugiego człowieka i zarazem roztropnością, nie poniżaj drugiej osoby, nie krzywdź drugiego człowieka, nie pomawiaj drugiego człowieka fałszywie, nie uprzedzaj się do drugiego człowieka, nie zazdrość drugiemu, przebacz drugiemu człowiekowi, nie chowaj urazy, działaj na korzyść drugiego człowieka, współczuj drugiemu w cierpieniu, myśl dobrze o drugim człowieku, okazuj szacunek drugiemu człowiekowi, nie zniesławiaj nikogo, nie obrażaj nikogo, nie inspiruj do złego, szanuj prywatność drugiego człowieka, nie bądź zachłanny, nie bądź chciwy, nie gromadź dóbr z uszczerbkiem dla interesu publicznego czy prywatnego, unikaj chęci panowania nad drugimi, nie pochwalaj złego, nie pomagaj w złym, nie kłam, nie kieruj się gniewem, nie bądź egoistą, bądź szlachetny, panuj nad sobą, nie bądź zawistny, dbaj mocniej o prestiż organizacji niż o własny prestiż, bądź sprawiedliwy ${ }^{19}$. Wskazane przykładowe normy prawa moralnego nie muszą mieć swojego bezpośredniego źródła w przepisach prawa administracyjnego. Nie oznacza to jednak, że nie mają być respektowane przy realizacji funkcji administracji publicznej. Można tu przytoczyć pogląd, że istnieje część prawa administracyjnego będąca zbiorem norm lub zbiorem postulatów, które „wprowadzają lub mogłyby wprowadzać w obręb prawa administracyjnego wartości uniwersalne, czyli wartości leżące poza tym prawem, niezbędne dla jego należytego funkcjonowania" ${ }^{20}$. Istnieje więc istotna podstawa do kierowania się $\mathrm{w}$ administrowaniu nie tylko normami wynikającymi bezpośrednio u regulowań prawnych. Powstaje jednak pytanie, czy urzędnicy mają świadomość tego, czym jest etyka w ich działaniach? A to pytanie rodzi następne: czy system kształcenia odpowiednio przygotowuje kandydatów do pracy w administracji publicznej, tak aby nie kierowali się tylko biernym wykonywaniem przepisów prawa?

\section{Rola szkolnictwa wyższego w przygotowaniu kadr administracji publicznej}

Kształcenie kadr dla administracji publicznej na uczelniach wyższych odbywa się przede wszystkim w ramach kierunku "administracja”. Są to studia dwustopniowe.

\footnotetext{
19 A. Błaś, J. Boć, J. Jeżewski, op. cit., s. 276 i n.

20 J. Zimmermann, Prawo administracyjne, wyd. 8, Warszawa 2018, s. 556.
} 
Pierwszy stopień, którym są studia licencjackie, trwa 3 lata podzielone na 6 semestrów. Drugi stopień, którym są studia magisterskie, trwa 2 lata podzielone na 4 semestry. Na drugi stopień przyjmowani są kandydaci będący absolwentami pierwszego stopnia studiów, niezależnie od kierunku studiów, które skończyli w ramach pierwszego stopnia, albo absolwenci drugiego stopnia lub jednolitych pięcioletnich studiów na innym kierunku kształcenia. Nie jest to w pełni korzystne rozwiązanie w zakresie przygotowywania kadr dla administracji publicznej, ponieważ kandydaci na studia drugiego stopnia kierunku "administracja” mogą nie posiadać podstawowej wiedzy z dziedziny nauk prawnych.

Kolejnym kluczowym kierunkiem studiów przygotowującym do pracy w administracji publicznej jest "prawo”. Na tym kierunku mogą to być jednolite studia magisterskie, które trwają 5 lat podzielonych na 10 semestrów. Coraz większe znaczenie mają jednak kierunki studiów określane jako „prawo z przymiotnikiem”, np. prawo gospodarcze, prawo w biznesie, prawo samorządowe. Są to studia prawnicze, ale nie dające uprawnień do przystępowania do egzaminów na aplikacje korporacyjne, a więc $w$ rezultacie studia te nie stwarzają możliwości do podejmowania pracy w tzw. zawodach prawniczych (np. sędzia, adwokat, prokurator). Absolwenci kierunków określanych jako prawo z przymiotnikiem stanowią więc dobrze przygotowaną i zróżnicowaną pod względem przygotowania zawodowego grupę kandydatów do pracy w administracji publicznej.

Jest jednak istotny mankament $\mathrm{w}$ programach kształcenia na kierunkach studiów związanych z dyscyplinami wiedzy zaliczanymi do dziedziny nauk prawnych. Tym mankamentem jest niedocenianie w przygotowywanych programach studiów planowania efektów kształcenia związanych z kształtowaniem osobowości pracownika, rozumienia misji administracji publicznej i znajomości zasad etyki, w tym etyki urzędniczej. W rozporządzeniu Ministra Nauki i Szkolnictwa Wyższego z dnia 26 września 2016 r. w sprawie charakterystyk drugiego stopnia Polskiej Ramy Kwalifikacji typowych dla kwalifikacji uzyskiwanych w ramach szkolnictwa wyższego po uzyskaniu kwalifikacji pełnej na poziomie 4 - poziomy 6- $8^{21}$ (rozporządzenie wydane na podstawie ustawy z dnia 22 grudnia 2015 r. o Zintegrowanym Systemie Kwalifikacji ${ }^{22}$ ). W załączniku do wskazanego rozporządzenia (Charakterystyki drugiego stopnia Polskiej Ramy Kwalifikacji typowe dla kwalifikacji uzyskiwanych w ramach szkolnictwa wyższego po uzyskaniu kwalifikacji pełnej na poziomie 4 - poziomy 6-8) w obszarze kształcenia w zakresie nauk społecznych zostały wskazane w kategorii wiedzy następujące efekty kształcenia: na poziomie 6 (studia I stopnia) - absolwent zna i rozumie cechy człowieka jako twórcy kultury

\footnotetext{
21

Dz.U. z 2016 r., poz. 1594.

22 Dz.U. z 2016 r., poz. 64 i 1010.
} 
i podmiotu konstytuującego struktury społeczne oraz zasady ich funkcjonowania (P6S_WG); na poziomie 7 (studia II stopnia i studia jednolite magisterskie) - absolwent zna i rozumie w pogłębionym stopniu cechy człowieka jako twórcy kultury i podmiotu konstytuującego struktury społeczne oraz zasady ich funkcjonowania (P7S_WG).

Kierunkowe efekty kształcenia dla kierunków studiów odpowiadających dyscyplinom zaliczanym do dziedziny nauk prawnych wynikające z uregulowań dotyczących kwalifikacji uzyskiwanych w ramach szkolnictwa wyższego stanowią wątłą podstawę do przygotowywania absolwentów, którzy będą rozumieli znaczenie i uwzględniali pozaprawne aspekty pracy w administracji publicznej. Absolwenci ci są wprawdzie na ogół odpowiednio przygotowani do analizowania aktów normatywnych, wydawania decyzji administracyjnych czy w ogóle rozumienia zasad systemu prawnego, ale brak im podstaw do uwzględniania w odpowiednim stopniu kwestii związanych z etyką działania i poszanowaniem przyjętych w społeczeństwie wartości. W programach studiów rezygnuje się - zgodnie z wymogami przepisów prawa - z profilu ogólnoakademickiego na rzecz profilu praktycznego. Studenci są przygotowywani do rozwiązywania konkretnych kazusów, a brakuje coraz częściej przekazywania przez nauczycieli akademickich wiedzy ogólnej, kształtującej postawy społeczne studiujących. W kierunku zmiany takiego stanu rzeczy powinny dążyć $w$ Polsce wyższe uczelnie, aby móc przygotowywać dobrze wykształcone kadry dla administracji publicznej.

\section{Bibliografia}

Barankiewicz T., Etyczne treści prawa do dobrej administracji, [w:] System prawa administracyjnego, t. 13: R. Hauser, Z. Niewiadomski, A. Wróbel (red.), Etyka urzędnicza i etyka stużby publicznej, Warszawa 2016.

Barankiewicz T., Etyka urzędnicza - pojęcie, [w:] M. Domagała, A. Haładyj, S. Wrzosek (red.), Encyklopedia prawa administracyjnego, Warszawa 2010.

Barankiewicz T., Urzędnika etyczne predyspozycje (cnoty), [w:] M. Domagała, A. Haładyj,

S. Wrzosek (red.), Encyklopedia prawa administracyjnego, Warszawa 2010.

Błaś A., Boć J., Jeżewski J., Administracja publiczna, Wrocław 2003.

Cieślak Z., Lipowicz I., Niewiadomski Z., Prawo administracyjne. Część ogólna, Warszawa 2002.

Griffin R.W., Podstawy zarządzania organizacjami, Warszawa 1996.

Izdebski H., Etyka urzędnicza a zasada rzetelności i sprawności działania instytucji publicznych w demokratycznym państwie prawnym, [w:] System prawa administracyjnego, t. 13: R. Hauser, Z. Niewiadomski, A. Wróbel (red.), Etyka urzędnicza i etyka służby publicznej, Warszawa 2016.

Koźmiński A.K., Piotrowski W. (red.), Zarzadzanie. Teoria i praktyka, Warszawa 1998. 
Skuczyński P., Infrastruktura etyczna administracji publicznej, [w:] System prawa administracyjnego, t. 13: R. Hauser, Z. Niewiadomski, A. Wróbel (red.), Etyka urzędnicza i etyka stużby publicznej, Warszawa 2016.

Sutherland J., Canwell D., Klucz do zarządzania zasobami ludzkimi. Najważniejsze teorie, pojęcia, postaci, Warszawa 2007.

Sześciło D., Mednis A., Niziołek M., Jakubek-Lalik J., Administracja i zarządzanie publiczne. Nauka o wspótczesnej administracji, Warszawa 2014.

Ura E., Ura E., Prawo administracyjne, Warszawa 2006.

Wiśniewski R., Etyka, [w:] Wielka Encyklopedia PWN, t. 8, Warszawa 2002.

Wrzosek S., System administracja publiczna. Systemowe determinanty nauki administracji, Lublin 2008.

Zimmermann J., Prawo administracyjne, wyd. 8, Warszawa 2018. 